preparation and characterization of ferritin for electron microscopic studies.

Reviewers normally delight to irritate authors by quoting with a slightly superior air of helpfulness a list of minor misprints and misstatements. Maddeningly enough, although $I$ have hunted for something of the sort for more time than I can afford, I have failed to spot any, though I cannot believe that in a book of this size there are not a few.

The price is rather shattering, though it does not sound so much when quoted as 30 dollars. Despite this the book is absolutely essential as a bench book for any laboratory doing fundamental research using immunological methods and very valuable as a reference book for any biochemical or pathological laboratory where such techniques may be needed from time to time, and nowadays their use is becoming more and more fashionable all the way from botany to biophysics.

\section{Relief of Symptoms}

Walter Modell, M.D., F.A.C.P. Second edition. Pp. $354+$ index. St. Louis: The C. V. Mosby Company. London: Henry Kimpton. 196r. 86s.

In principle, a volume devoted to the relief of symptoms is admirable, and the best way to discuss its value is to put it into daily use, turning constantly to it for guidance. Indeed, it is the author's declared intention that it should be a practical guide to the problems of providing the patient with relief from distress. In order to succeed, such a guide and companion should have a first-rate index, the minimum of verbosity, skilfully constructed charts to equate various symptoms with their means of relief, and it should, of course, be up to date. This book is deficient in some measure in all these respects. The relief of liver dysfunction in the chapter on unconsciousness is dismissed in the fullblown sentence 'Diet and nutrition would seem to have a bearing, but there is no uniformity of opinion on which elements in diet spare the liver, which support it, and which stimulate it, and it is certain that no matter how one feeds the patient, orally or parenterally, he will be going counter to the advice of one expert or another'. It is well known that methyltestosterone and norethandrolone can provide dramatic relief of the intolerable pruritus associated with jaundice, but this does not appear to be the author's experience. Those who would wish to consult the book for advice in the management of one of the most painful conditions of man, orchitis, would do so in vain; neither is it possible to find the relief of post-herpetic neuralgia, renal or biliary colic, or photophobia and blurred vision due to uveitis. It is possible that the principles enunciated under the long chapter on pain are intended to cover all such contingencies. Spironolactone is mentioned in one sentence and no reference is made of its combined use with chlorothiazide for the relief of resistant œdema.

With a less discursive style of writing it could be made a more comprehensive, shorter and less expensive book to cover one of the most important aspects of medicine.

\section{Uveitis and Toxoplasmosis}

E. S. Perkins, Ph.D., M.D., F.R.C.S. Pp. vi +142 + index, illustrated. London: J. \& A. Churchill. 1961. 30s.

Professor Sorsby has estimated that uveitis is the cause of blindness in $2.5 \%$ of all blind persons in England and in $8.3 \%$ of those in the fourth decade.

During the last few years a special Uveitis Clinic in the Institute of Ophthalmology, London, has been accumulating data on the problem, and its results are now reported in detail. The analysis is based on the case records of 1,718 patients, most of whom have been referred to this special clinic from the out-patients' clinics of Moorfields Hospital. The material is classified into anterior, posterior and generalized uveitis and further subdivided into acute and chronic. The cause of the inflammation in each of these categories is analysed and certain generalizations emerge. Acute anterior and generalized uveitis are associated with chronic prostatitis, Reiter's syndrome, ankylosing spondylitis, sacro-iliitis and plantar fasciitis; chronic anterior uveitis is associated with heterochromic cyclitis; and toxoplasmosis appears to be the commonest cause of acute posterior uveitis. Sarcoidosis seems to be sprinkled throughout most groups; it comprises $3.2 \%$ of the whole series, but its incidence varies from I I \% of patients with chronic generalized uveitis to $1 \%$ of women or nil in men with chronic posterior uveitis. In most instances its clinical appearance is not characteristic, and the diagnosis of ocular sarcoidosis is established by evidence of the disease elsewhere, chest radiographic abnormalities, and by means of the Kveim test. The diagnosis of toxoplas mic uveitis was likewise indistinct until the present survey, but largely as a result of the author's pioneer work it is now clinically recognizable as a focal choroiditis involving the posterior half of the fundus, particularly near the disc, the macula and the main retinal vessels.

It is depressing to realize our ignorance concerning the atiology of uveitis. The results of this survey emphasize present limitations of knowledge and point the way to further studies, including the currently fashionable concept of auto-immunity. It is hoped that further investigations will be planned and executed in the same admirable manner as the present survey.

This monograph is essential reading for all postgraduate students in ophthalmology, and is also strongly recommended to all general physicians since uveitis is but one facet of a general disease.

\section{Psychosomatic Aspects of Pædiatrics}

Study Group of the Society for Psychosomatic Research held at the Royal College of Physicians in May, 1959. Edited by RoNALD MAcKEITH and Joseph SANDler. Pp. xiii + r 55. Oxford, London,

New York and Paris: Pergamon Press. I96r. 50s.

This book should be carefully studied by all children's doctors who, to use contemporary jargon, are psychiatrically orientated. Today, as the incidence of organic disease in the young declines, there is a growing awareness amongst pædiatricians of the relatively increasing role played by emotional factors in the causation of children's illnesses. At the same time there must often be a feeling of inadequacy on the physician's part when dealing with such cases because past medical training, with its scant regard for the psychological implications of ill health, has left many of the present generation of doctors ill equipped to deal with psychosomatic problems. Doubtless, Ronald MacKeith and Joseph Sandler, the organizers of the Study Group and co-editors of this report, had all this very much in mind when they conceived the idea of this meeting, arranged an outstanding programme and invited an audience predominantly composed of children's specialists.

Of particular interest to the clinician will be the papers on constipation and encopresis and on recurrent pains in childhood, the lucid account of identification by Sandler and the chapter reporting the sessions at which Miss Anna Freud answered brilliantly a wide range of questions from the pædiatricians in the audience. Other matters discussed and recorded in this 
work include the child and his symptom, the theories of psychological development in children and problems of research in the psychosomatic field. The meeting was notable for the high standard of contributions from the floor, and the editors have been wise to include these because they add to the pleasure of reading the book.

This is a production of considerable merit and the editors and contributors, as well as the publishers, are to be congratulated. Some may consider the book a little expensive at 50 s., but they can rest assured that it is well worth the money.

\section{Functions of the Blood}

Editors: R. G. MaCfarlane, M.A., M.D., M.R.C.S., F.R.S.; A. H. T. RoBb-SMITH, M.A., M.D., F R.C.P. Pp. xiii +635 , illustrated. Oxford: Blackwell. I961. £6.

The book is an attempt to provide a unifying approach to the study of blood and its functions. It is a presentation of biological strategy rather than the technique of research and so it avoids becoming another review of partially digested and disconnected facts. It most certainly achieves its object in being of interest to hæmatologists and workers in a wide range of related subjects. The width of the approach deserves the highest praise and increases its recommendation to the seasoned research worker and also the novice. There is no doubt that it is not a book for the examination candidate.

H. P. Wolvekamp writes on the evolution of oxygen transport. He discusses many aspects of oxygen transport in the circulating blood without blood pigments, the significance of blood pigments in oxygen and carbon dioxide transport, the properties of blood pigments, oxygen storage by cellular hæmoglobin, the states of carbon dioxide in the blood, and the general properties of gas transfer in mammalian blood. He reviews the gaps in our knowledge due to technical difficulties. The evolution of the human red cell written by $\mathrm{H}$. Lehmann and R. G. Hunstman provides a discussion of the nature of the hæmoglobin molecule, the function of its iron atoms and their position, and the external influence of the hæm group. The evolutionary implications are discussed of the role of hæmoglobin and the red cell in the higher invertebrates, early chordates and the vertebrates together with the maturation of the human red cells and the significance of the reticulocyte are also presented. Chapters are given by William Holmes and L. V. Heilbrunn respectively to the evolution of the leucocyte and the hæmostatic mechanisms The reason for the inclusion of these evolutionary aspects of hæmatology is the hope that they are capable of throwing light on unsolved problems in higher animals. They make interesting reading, but are dealt with at a length which many readers will find unnecessary. The data might well have been more precisely informative.

Workers in the more applied medical sciences will certainly find greater enjoyment from the other chapters. These include the significance of the red cell antigens by A. E. Mourant, which contains a brief summary of the association of blood groups and diseases. In a provocative review, Oliver $P$. Jones writes on the influence of a disturbed metabolism on the morphology of blood cells. He deals primarily with hæmatological cytology as viewed with a bright field microscope, but he also draws upon many references from dark phase, phase, interference, fluorescence, ultra-violet and electron microscopy to support his arguments and to delineate modern trends in diagnosis and research. Unfortunately by delaying the definition of a number of terms that may be in everyday use by the electrôn microscopist, the routine hæmatologist might find sonor difficulty in fully understanding this chapter at the initial reading.

The homeostasis of the blood-cell elements is coof tributed by Howard R. Bierman. Nutritional and plasma hæmatopoietic factors are discussed togethe with the mechanisms of erythrocyte, leucocyte and platelet equilibrium and the pathological factors it fluencing these mechanisms. Some of the data in thes chapter suffers from being out of date and the authō departs from the aim of the editors in having to recour to detailed lists of data, some of which contain cona monplace information.

The maintenance of the milieu interieur by J. $\mathbb{P}$ Ball is limited to 20 pages, which is regrettable. The effect of its disturbance on the blood cells and proteins is entirely omitted. What there is is good, but a littdo more would have been satisfying and more in keeping with the space given to other subjects. The delight historical introduction of the growth of knowledge $\bar{\theta} f$ the functions of the blood by A. H. T. Robb Smith comp; prises more than 50 pages.

D. S. Robinson deals with the function of the blood in the transport of fatty acids. The term "fatty acios he used includes both esterified and non-esterified states of the fatty acid molecule, and this leads to somit confusion in reading. The correct chemical nomets clature would certainly have been more satisfactor The discussion is divided into a consideration of $=\mathrm{a}$ hypothetical post-absorptive state and a comparison of this with that following a fatty meal and that when fatty acids are mobilized from the fat depots for utiliz tion by the tissues.

Chapters on chemotaxis and phagocytosis by $\mathrm{H}$. Hâr and complement by $O$. J. Plescia and M. Heidelbeoger are in keeping with the high standards of this boto Outstanding contributions are made by R. G. Naßs farlane and F. Haurowitz. The former deals with the normal blood flow and the changes in inflamed tissues, blood coagulation, clot retraction and fibrinolysis. The latter discusses the plasma proteins, their carrier func. tion, their formation and breakdown, and their function in the immunological response.

This book is delightfully produced and illustrated The bibliography, which is obviously carefully selected, is enormous.

To anyone interested in blood and its functions in health or disease, the commendation is ' read it'. The criticisms made are minor in comparison with the value of the book as a whole. The editors are to be con gratulated in its aim and its achievement.

\section{Proceedings of the Fourth International Congres on Chemical Chemistry}

Edinburgh, 14th to 19th, 1960. Pp. xvi +2 ig illustrated. London: Butterworth. I96r. 35s.

This volume contains a full test of the presidential address by Sir Rudolph Peters, and of the symposia ôn plasma protein turnover in disease, the mechanisms of urine production, enzymes in clinical chemistry and congenital abnormalities of metabolism, with the $\mathrm{e}$ suing discussion. In addition brief extracts of the communications (sometimes very brief) have bees included. The accounts of the symposia can warmly recommended both to those interested in the subject and to the general reader as authoritative and reasonably up-to-date reviews. In particular, a clear exposition is given of the 'counter current' theory \&f kidney function. However, the summaries of the oth $\mathrm{r}$ communications are of doubtful value because of therr brevity. 